\title{
Erratum to: Characterization of a KCS-like KASII from Jessenia bataua that Elongates Saturated and Monounsaturated Stearic Acids in Arabidopsis thaliana
}

\author{
Ooi-Kock Teh $\cdot$ Umi Salamah Ramli
}

Published online: 16 December 2010

(C) Springer Science+Business Media, LLC 2010

\section{Erratum to: Mol Biotechnol}

\section{DOI 10.1007/s12033-010-9350-x}

The affiliation of the sample provider, Dr. Rajanaidu a/l Nookiah, was mistakenly omitted from the Acknowledgments in the original publication. The Acknowledgments should read, "We thank the Director-General of the
Malaysian Palm Board for permitting to publish this article, Dr Rajanaidu a/l Nookiah, Breeding \& Genetics Group Advanced Biotechnology \& Breeding Centre MPOB, for providing the Jessenia samples, and Mahadzir b. Jaafar for technical assistance with the gas chromatography analysis of fatty acids."
The online version of the original article can be found under doi: 10.1007/s12033-010-9350-x .

O.-K. Teh · U. S. Ramli ( $\square)$

Malaysian Palm Oil Board (Advanced Biotechnology

and Breeding Centre), No. 6, Persiaran Institusi, Bandar Baru

Bangi, 43000 Kajang, Selangor, Malaysia

e-mail: umi@mpob.gov.my

O.-K. Teh

e-mail: okteh@mpob.gov.my 